\title{
Roads Not Taken: Victorian Science, Technical Education, and Canadian Schools, 1844-1913
}

\author{
Suzanne Zeller
}

Historians have carefully examined the tortuous development of Canadian technical education, defined as the means of imparting skills, techniques, and applied principles in preparation for the practice of a trade or profession. They rightly attribute a growing "movement" for its inclusion in public education during the last quarter of the 19th century to the social and economic challenges of industrialization and urbanization. This movement not only raised concerns about children and youth but broadened to include adult education, drawing inspiration from successful technical schools abroad, and gaining momentum from Philadelphia's Centennial Exposition in $1876 .{ }^{1}$

To investigate the deeper historical foundations of this technical education movement is to evoke James Hutton's famous geological adage, "no vestige of a beginning,-noprospect of an end." The 1913 Royal Commission on Industrial Training and Technical Education formulated a "blueprint for the implementation in Canada of the 'new education"' which combined intellectual development with preparation for entrance into industrial society, ${ }^{2}$ but proposed only the vaguest strategies for integrating technical education into the country's institutional mainstream. Although 19th-century Canadians staked their material, social, and moral progress on modern science and technology, their policymakers never decisively embraced technical education as indispensable to the fulfilment of such ambitions.

One explanation for this reluctance rests with the general consensus that Canada's economic future, including its industrial development, relied almost exclusively upon staple production. The Laurier government's "wary indifference" toward technical education thus stemmed not only from constitutional compli-

${ }^{1}$ R.M.Stamp, "The Campaign for Technical Education in Ontario, 1876-1914," unpublished PhD thesis, University of Toronto, 1970; Neil Sutherland, Children in English-Canadian Society repr. (Waterloo: Wilfrid Laurier University Press, 1999), Part IV; David S. Enns, "Technical Education and Industrial Training in Early $20^{\text {th }}$ century Canada: The Royal Commission of 1910," unpublished MA thesis, Dalhousie University, 1982; Janet Guildford, "Technical Education in Nova Scotia, 1880-1930," unpublished M.A. thesis, Dalhousie University, 1983; B. Anne Wood, Idealism Transformed (Montréal/Kingston: McGill-Queen's University Press, 1985); Donald MacLeod, "Practicality Ascendant: The Origins and Establishment of Technical Education in Nova Scotia," Acadiensis 15, 2 (Spring 1985): 53-92; Robert Gagnon, "Les discours sur l'enseignement pratique au Canada français, 1850-1900," in Marcel Fournier, Yves Gingras, and Othmar Keel, eds., Sciences et médecine au Québec (Québec: Institut québecois de recherche sur la culture, 1987), 19-39.

${ }^{2} \mathrm{~S} . J$. Gould, Time's Arrow, Time's Cycle (Cambridge, Mass.: Harvard University Press, 1987), 63; Sutherland, Children, 199-200; J.R. Millard, The Master Spirit of the Age (Toronto: University of Toronto Press, 1988), 13, 25.

(C) Historical Studies in Education/Revue d'histoire de l'éducation 12, nos. 1/2 (2000): 1-28. 
cations, but also from economic facts that placed the highest levels of technological sophistication beyond the country's reach. ${ }^{3}$

Beneath the noisy jockeyings of political factions and social classes over technical education lurked a deeper conflict. Canadians had inherited the Western conceptual distinction between ars (the mode of thought of the philosopher) and ingenium (that of the mechanic). That classical dualism lay behind the paternalistic relationships that demarcated liberal and technical communities, including separate educational streams. Schools cultivated liberal arts for an aspiring bourgeoisie, and apprenticeships imparted trade and craft secrets to selected initiates. ${ }^{4}$

Victorian science, comprising a growing body of knowledge and a method of acquiring it, sought to straddle these two educational streams. It was remarkably adaptable at major economic junctures: free trade from the 1840s; depression from the 1870s; and corporate expansion from the 1890s. Science's public image changed accordingly from liberal art, to research ideal, to industrial research. These transitions reverberated in educational policy. Science's entry into liberal arts curricula was followed by the appearance of science schools and the rise of industrial research programmes. Each phase showed science to be a powerful solvent of traditional structures, insinuating itself between the mechanic and hands-on training, and reworking intellectual, political, and economic alliances. Promoters of science set about revising educational curricula to make liberal knowledge more practical and technical knowledge more theoretical. They used the cause of technical education as a Trojan horse, benefiting from educators' disagreements over how and where to bridge the liberal/technical divide.

Because certain habits of thought died hard, the scientization of technical education fuelled chronic conflicts over scarce educational resources. Those conflicts in turn caused long-term jurisdictional and curricular tensions in education. Canadians thus confronted challenges to classical dualism, and responded in their inimitable way.

${ }^{3}$ Robert Craig Brown and Ramsay Cook, Canada 1896-1921: A Nation Transformed, Canadian Centenary Series (Toronto: McClelland and Stewart, 1974), 83-95.

'Steven Shapin and Simon Schaffer, Leviathan and the Air-Pump (Princeton: Princeton University Press, 1985) 129-31; P.-H. Audet, “Apprenticeship in Early Nineteenth Century Montréal," unpublished MA thesis, Concordia University, 1976; J.-P. Hardy and D.-T. Ruddel, Les apprentis artisans à Québec, 1650-1815 (Montréal: Les presses del'Université de Québec, 1977); Bryan D. Palmer, Working-Class Experience, rev. ed. (Toronto: McClelland and Stewart, 1992), Ch. 1. 


\section{NEVER THE TWAIN}

One particular manifestation of the classical mind-body dualism in British North America-systematic liberal education as public instruction during the 1840 s -ensured the exclusion of its technical counterpart. Dialogues among "school promoters" expressed a powerful middle-class evangelical impulse, with education central to its "civilizing" mission. ${ }^{5}$ This crusade allocated to mechanics' institutes, boards of agriculture, boards of arts and manufactures, and similar institutions separate and unequal roles relative to formal schools. Over time, supporters of rival "Ryersonian" and "Dawsonian" perspectives clashed in seeking to control "practical" education.

\section{Rival Royal Roads}

Egerton Ryerson (1803-82), Methodist circuit rider, principal of Victoria College, and Chief Superintendent of Public Instruction for Canada West from 1844 , in many ways epitomized the evangelical thrust of public schools. His maritime counterpart, the geologist J.W. Dawson (1820-99) who became Nova Scotia's Superintendent of Education in 1850, also believed public instruction should be universal, compulsory, non-denominational and, in emphasizing liberal arts, eminently practical. The two superintendents thus shared common interests in the creation of public school systems. Ryerson's Loyalist background, parallelling Dawson's Scottish heritage, elevated science to a higher plane than traditionally the case in liberal education. They combined educational ideals with Baconian confidence in science's power (according to a contemporary) to pour "a flood of light... upon every operation, and open the way to profit, enterprize, and improvement." In this sense, Ryerson and his fellow "school promoters" transcended their Georgian upbringing: while continuing to esteem the classics, they advocated applications of science to the arts of everyday life. ${ }^{6}$

Appealing to largely agricultural colonial societies, the Ryer/Dawsonian modes of superintendence facilitated science's infiltration of liberal school curricula through their plans to teach scientific agriculture. In the age of Agricultural

sAlison Prentice, The School Promoters (Toronto: McClelland and Stewart, 1977).

${ }^{6} \mathrm{~J}$. Donald Wilson, "The Ryerson Years in Canada West," in J.D. Wilson et al., eds., Canadian Education (Scarborough, Ont.: Prentice-Hall, 1979), 218; B. Anne Wood, God, Science and Schooling (Truro, N.S.: Nova Scotia Teachers College, 1991) 47-57; United Church Archives (Toronto), Egerton Ryerson, Inaugural Address on the Nature and Advantages of an English and Liberal Education (1842) 22; British American Cultivator 1, 1 (1842): 4-5. Montreal Gazette, "Education and McGill College," 20 July 1849; "Lower Canada College," 20 July 1852; Nova Scotia, House of Assembly, Joumals (1851) App. 53, J.W. Dawson, "Preliminary Report of the Superintendent of Education;" review of Dawson, "Report on the Schools of Nova Scotia, for the Year 1851," The Provincial (1852): 193-4; New Brunswick, House of Assembly,Joumal (1855), App.: Education, J.W. Dawson to J.H. Gray, 15 December 1854, cc-ccii; R.D. Gidney and W.P.J. Millar, Inventing Secondary Education (Montréal/Kingston: McGill-Queen's University Press, 1990) 14, 158-60. 
and Industrial Revolutions, colonists could ill afford to ignore the relentless advance of useful knowledge. Addressing the British American Cultivator in 1842, James Hunter of Newmarket urged that common schools teach agricultural sciences. Anticipating a "moral revolution," Hunter rhapsodized: "In a few short years we shall find cabinets of natural, rare, and valuable curiosities formed in every family," with "books, maps, and simple apparatus, for trying chemical experiments, in the hands of every youth," and mechanics' institutes and lyceums in every village, "to discuss the natural sciences, and to aid and assist each other in the pursuit of knowledge."

Ryerson's European educational tour of $1844-45$ persuaded him Canada's economic future lay in applying the motor of rational scientific principles to the labours of the field, through liberal arts programmes augmented by botanical gardens and model farms. Dawson too saw agriculture "suffering from a deficiency of scientific knowledge more than from any other cause." He wanted schools to promulgate "the natural laws on which its operations depend," using textbooks, apparatus, and teacher training in agricultural chemistry.

Agriculture and the mechanical arts have in our day established for themselves so close a union with chemical and mathematical science, that when separated from these intellectual aids, as they of necessity are to a great extent in newly settled countries, they cannot attain their full growth. ${ }^{.8}$

After mid-century, both superintendents advanced their careers as science promoted institutional growth. Ryerson's alliance in 1855 with the Toronto Magnetic and Meteorological Observatory's director, J.H. Lefroy (1817-90), transformed his senior county grammar schools into an auxiliary chain of meteorological stations. That same year Dawson became principal of McGill College, and inaugurated a chair of meteorology to apply Dr. Charles Smallwood's (1812-74) talents to similar public service in Canada East.'

Parallel paths now diverged. While Dawson staked his career on university reform, Ryerson encountered new rivals. McGill, Toronto, Laval, Queen's, Dalhousie, and New Brunswick sought to modernize their liberal arts curricula, appointing new professors of science eager to enhance their status. Expecting his Normal School to serve as a provincial agricultural college, Ryerson disputed the University of Toronto's proposed new chair of agriculture, guaranteed by statute and favoured by the provincial Board of Agriculture. Agricultural reformers nevertheless secured the appointment of George Buckland (1804-85) as professor of agriculture in $1852 .^{10}$

\section{'British American Cultivator, 5.}

${ }^{8}$ Dawson, "Preliminary Report"; J.W. Dawson, First Lessons in Scientific Agriculture (1864), 15; Dawson to Gray, cci; Wood, God, Science, and Schooling, 47.

'Montréal Gazette: "University of McGill College," 6 November 1855; “Meteorology,"12 May 1856; "Lectures on Meteorology," 8 January 1857. Suzanne Zeller, Inventing Canada (Toronto: University of Toronto Press, 1987), Ch. 7.

10a Proceedings of the Select Committee," (1860) in J.G. Hodgins, ed., Documentary History of Education in Upper Canada (Toronto, 1906), 15: 212-15; Zeller, Inventing Canada, 206-8. 
Buckland failed in the short run to create a viable agricultural programme. His rural constituents proved so suspicious of "book-farming" that an impatient provincial legislature abolished his position in 1860 . Ryerson failed in the long run to control the momentum of educational change by staving off further moves to loosen the classics' longheld grip in university curricula. In contrast, even before going to McGill, Dawson rejected proposals to concentrate "practical scientific studies" in "any institution inferior to a Provincial College. No increase or improvement of Schools lower than this in their range and endowment," he maintained, could "attain fully the end of bringing science to bear on the industrial arts of the country."11

These competing perspectives pitted educational levels one against another, promising frustration for future efforts to naturalize technical education in Canadian schools. By infusing public education with science as underpinning technical knowledge, Ryerson, Dawson, and other "school promoters" began interblending the two traditional educational streams. In so doing they were undermining cultural assumptions to which they and many contemporaries continued in principle to subscribe. This potentially revolutionary path encountered a roadblock: conflicting expectations over where in the educational system, and to what extent, to unravel their common outlook - and who should be in control. ${ }^{12}$

From the beginning, practical courses fit uneasily into British North America's liberal educational mainstream. Agriculture's early demise at the University of Toronto echoed in the barren beginnings of civil engineering courses at Toronto, $\mathrm{McGill}$, and New Brunswick, despite hopes raised by an 1850 s railway boom for career alternatives to the glutted legal professions. Analogous attempts to teach pharmacy independently of medicine also foundered a decade later. Dawson's success in establishing a chair of applied chemistry and mineralogy at McGill in 1862 was soon negated when Thomas Sterry Hunt (1826-92) returned to the United States in $1869 .{ }^{13}$

"Dawson to Gray, cci; Dawson, “University of McGill College," 2; "McGill College," Montréal Gazette, 29 August 1857, 2; Suzanne Zeller, "Merchants of Light': The Culture of Science in Daniel Wilson's Ontario, 1853-1892," in Elizabeth Hulse, ed., Thinking With Both Hands (Toronto: University of Toronto Press, 1999), 117-23.

12“University of McGill College”; J.W. Dawson, Inaugural Address (Montréal, 1855), 9-21; R.D. Gidney and W.P.J. Millar, Professional Gentlemen (Toronto: University of Toronto Press, 1994), Chs. 1, 17.

${ }^{13}$ Montréal Gazette: "Civil Engineers," 5 July 1853; "McGill College," 20 November 1855; “University Intelligence," 29 April 1862; "Montréal Chemists' Association," 3 October 1868; "Mining and Metallurgy," 27 February 1869. "University of McGill College," 2; Gidney and Millar, Professional Gentlemen, 357-59; C.R. Young, Early Engineering Education at Toronto (Toronto: University of Toronto Press, 1958), Ch. 2; Stanley Brice Frost, McGill University (Montréal:McGill-Queen's University Press, 1980) 1: 188; Robin S. Harris, A History of Higher Education in Canada (Toronto: University of Toronto Press, 1976), 72-3, 164-5; R.J. Clark, "Professional Aspirations and the Limits of Occupational Autonomy: The Case of Pharmacy in Nineteenth-Century Ontario," Canadian Bulletin of Medical History 8 (1991): 43-63. 
Roads Rejected

Canada's technical community fell between the cracks in these nascent educational structures. By the 1850 s, industrialization diverted attention from farmers to mechanics and artisans, and to educational prospects for adult workers. Reports of the London (1851) and Paris (1855) Exhibitions' colonial displays of natural resources also emphasized embarrassing international discrepancies in manufacturing skills. Dire judgments were voiced of the Crystal Palace as "the Sadowa of English competition," with British manufacturers "worsted and humiliated by French taste and skill," and these echoed in the colonies. "The time had arrived," recalled the superintendent of Ontario's Educational Museum and Library in 1880 , to concede that "the great triumphs of manufacturing skill are dependent upon mechanical inventions or discoveries in chemical and physical science."14

Canada's provincial legislature responded in 1857 by appointing Boards of Arts and Manufactures to improve "mechanical arts" and by promoting "mechanical science" through museums, libraries, lectures, and workers' colleges. With the public expecting to see new schools of practical science, the Board of Arts and Manufactures envisioned Mechanics' Institutes as stepping-stones toward this goal. Established in many towns since the 1830s, Mechanics' Institutes offered convenient venues for evening classes in mechanical philosophy, chemistry, and other scientific bases for crafts and trades. Dawson extended his rationale for farmers' scientific education to artisans, mechanics, and miners. Mechanics' Institutes could thus fulfill their "great purpose" as "the college of the people," ensuring production and diffusion of useful knowledge through public demonstrations of science as exciting, accessible, and marketable. ${ }^{15}$

In 1861 Canada West 's Board of Arts and Manufactures funnelled a workers' accreditation system through the province's Mechanics' Institutes to standardize approaches to mathematics, mechanics, natural philosophy, and chemistry. In an age prolific with contests, enrollment concerns prompted cash incentives for Mechanics' Institutes to recruit a handful of students to evening classes, and

${ }^{14}$ Montréal Gazette: “McGill College," 20November 1855; "Science for Ladies," 13 November 1868. Richard Lewis, "Mechanics' Institutes, and the Best Means of Improving Them," Canadian Monthly and National Review 10 (1876): 225-6; Walter Smith, Technical Education and Industrial Drawing in Public Schools (Montréal, 1883) 16; Ontario, Sessional Papers, XIII, Part IV (1881), App. 46: S.P. May, "Report on Mechanics' Institutes," 1-11, 38-40.

${ }^{15}$ Dawson, First Lessons, 11, 15-17. Journal of the Board of Arts and Manufactures of Upper Canada: H.Y. Hind, "Introduction, ${ }^{*} 1,1$ (January 1861): 1-3; "Classified Catalogue of the Free Library of Reference," 1,9 (September 1861): 234-9; " $S$ " to editor, 1, 3 (March 1861): 74; "RL" to editor, Joumal of the Board of Arts and Manufactures of Upper Canada 1,7 (July 1861): 184-5, 1, 8 (August 1861): 211-2. May, "Report," 2-3, 37; Lewis, "Mechanics' Institutes," 223-5; "Science for Ladies"; Martin Hewitt, "Science, Popular Culture, and the Producer Alliance in Saint John, N.B.," in Paul A. Bogaard, ed., Science and Society in the Maritimes (Fredericton: Acadiensis Press, 1990), 243-76. 
nurture even two to provincial examinations. Only a dozen Mechanics' Institutes at most annually attained these goals. ${ }^{16}$

Troubled since their inception by struggles to survive, Mechanics' Institutes suffered further when Boards of Arts and Manufactures intercepted their legislative grants. The difficulty of offering evening classes under desperate financial circumstances raised the question of public funding for workers' education, justified by then-expansive literacy and the growth of the franchise. Toronto's Mechanics' Institute, enjoying high enrollments as smaller centres closed, attracted $100-200$ students to evening classes annually between 1862 and 1867 . Observers welcomed these results as signalling a public appetite for science. This exception proved the rule, in the unprecedented financial burden imposed by a modern technical education which, even for willing workers, required laboratories, apparatus, and instructors. ${ }^{17}$

The dream that governments would provide technical education in British North America took wing during the 1860 s. Confederation raised expectations of the new federal power, but the Paris Exposition again "painfully impressed the minds of Englishmen" with "their actual and growing inferiority in important arts and manufactures to better educated nations." A "near-panic" launched the mother country's technical education movement, with British North Americans' own "disgraceful at least, if not alarming" failure to adopt successful initiatives in technical education leaving them "as far behind... as we were in $1851 . " 18$

${ }^{16} J$ oumal of the Board of Arts and Manufactures of Upper Canada: H.Y. Hind, "Examination of the Candidates for Certificates, "1, 1 (January 1861): 8-14; Toronto Mechanics' Institute to editor, 1, 9 (September 1861): 244; "RS" to editor, 1,9 (September 1861): 244-45; "The Education of Our Young Mechanics," 5, 9 (September 1861); “Annual Examinations," 6, 1 (January 1866). "McGill University," Montréal Gazette, 28 April 1864; Association of Mechanics' Institutes of Ontario, Rules and Regulations for Awarding Prizes (Toronto, 1873); W. Edwards, "Mechanics' Institutes in Ontario," Scientific Canadian 8, 8 (August 1880): 247; May, "Report," 18.

"May, "Report," 10-11. Joumal of the Board of Arts and Manufactures of Upper Canada: William Edwards, "Mechanics' Institutes as Educational Institutions for the Adult Industrial Classes," 4, 2 (February 1864): 33-5; "Toronto Mechanics' Institute," 5, 6 (June 1865): 151-3; "Mechanics' Institute Classes," 5, 8 (August 1865): 200-2; “Adult Education and Mechanics' Institute Classes," 5,1 (September 1865): 3-4; "The Annual Examinations, and Evening Class Instruction," 7,1 (January 1866): 4-5; “Toronto Mechanics' Institute, 6, 6 (June 1866): 157-9; "Toronto Mechanics' Institute Evening Classes," 6, 11 (November 1866): 288-90; "Toronto Mechanics' Institute Classes," 7, 11 (November 1867):296. S to editor, 74; cf. John Laurent, "Some Aspects of the Role of the Institutes in Technical Education in New South Wales 1878-1916," in P.C. Candy and John Laurent, Pioneering Culture: Mechanics' Institutes and Schools of Arts in Australia (Adelaide: Auslib Press, 1994), 184-5.

${ }^{18} \mathrm{Joum}$ al of the Board of Arts and Manufactures of Upper Canada: "The Toronto Mechanic's Institute Classes, 7,5 (May 1867): 121; “Canada-Her Educational and Industrial Future," 7,7 (July 1867): 169-73; Artificer, "Technical Education," 7,9 (September 1867): 234. Journal of the Joumal of the Board of Arts and Manufactures of Upper Canada: Ontario [O]: "The Paris Exhibition in Its Relation to Industrial Instruction," 7, 10 (October 1867): 263; "Art Education for Artisans in Paris," 7, 10 (October 1867): 267; "Technical Education," 7, 10 (October 1867): 255-9.J.W. Dawson, “On Science Education Abroad," Montréal Gazette, 19 
Instead of framing a national response, the British North America Act assigned education to the provinces. Ontario promptly abolished its Board of Arts and Manufactures, reinstating Mechanics' Institutes' annual grants for technical and scientific classes. Perennial hopes for student numbers dimmed, despite the Toronto Pharmaceutical Society's sponsorship of local Mechanics' Institute chemistry courses from 1869. Over the next decade public hopes for technical education turned to public schools. High schools and local professionals were expected to furnish Mechanics' Institutes with science instructors. In Ontario, control over Mechanics' Institute science courses steadily devolved to the Department of Education, which could well afford to let Mechanics' Institutes atrophy altogether. Science had infiltrated public education as a modern mainstay of the liberal arts, but for the time being its practical offshoots remained relegated to the shadows. ${ }^{19}$

\section{NEW DIRECTIONS, OLD DIRECTIVES}

Contemporary with the Ryer/Dawsonian conflict over the proper venue for technical education, Scottish Common Sense philosophy dominated EnglishCanadian education. Emphasizing the development of separate mental and physical "faculties," Common Sense reinforced the classical mind-body dualism which neither Ryerson nor Dawson would deny. ${ }^{20}$ Their differences intensified during the 1870s. Ryerson lost of control over schools of applied science and technology, further marginalizing the technical community from the educational mainstream.

\section{Roads Rerouted}

The centralizing of science teaching in public institutions after Confederation followed mounting accusations that a liberal education could be considered practical no longer. The growth abroad of science departments and science degrees, of polytechnics and schools of applied science, of philosophical apparatus, of chemical laboratories, and of metallurgical furnaces outshone Canadian plans to transform Mechanics' Institutes into schools of art and design.

November 1870; D.S.L. Cardwell, The Organization of Science in England, rev. ed. (London: Heinemann Press, 1972), 111.

${ }^{19}$ May, "Report," 11-37, 48-61, 66-74. Journal of the Board of Arts and Manufactures of Ontario: "Technical Education," 7, 10 (October 1867): 255-9; "Aid to Mechanics' Institutes," 8, 1 (January 1868): 30; "Evening Class Instruction for Artisans," 7, 10 (October 1867): 254; "Technical Education," 8, 1 (January 1868):30-1. Artificer, "Technical Education," 234.

${ }^{20}$ A.B. McKillop, A Disciplined Intelligence (Montréal: McGill-Queen's University Press, 1979). In contrast, ultramontane clerics in Quebec actively combatted such dualism in FrenchCanadian education by reviving a pre-Cartesian Thomist philosophy: Yvan Lamonde, La philosophie et son enseignement au Québec (LaSalle, P.Q.: Hurtubise, 1980), 158-9. 
A rapid mitosis of Victorian physical sciences also left the familiar subdivisions of natural philosophy and chemistry hopelessly inadequate. ${ }^{21}$

Scientific agriculture found its way into institutionalized education during these years through the Ontario School of Agriculture, established in Guelph in 1874, renamed Ontario Agricultural College and Experimental Farm in 1880, and affiliated with the University of Toronto in 1888. Other schools of scientific agriculture (established at Truro in 1885 and Oka in 1893) complemented the Dominion Experimental Farms directed by William Saunders (1836-1914) from $1886 .{ }^{22}$

The road to technical education for Canadian workers had yet to be blazed. As in agricultural, scientific practice was changing. A new professional generation included J.W. Dawson's son, G.M. Dawson (1854-1901), a star graduate of the Royal School of Mines who joined the Geological Survey of Canada in 1875. Others arrived as university faculty professing the German research ideal: James Loudon (1841-1916) in mathematics and physics at Toronto from 1875, J.G. MacGregor (1852-1913) in physics at Dalhousie from 1876, and kindred spirits who scattered throughout the colonies advocating the pursuit of knowledge independently of religion and metaphysics. Amid calls for practical courses at every educational level, the elder Dawson led the universities in wresting the initiative from Mechanics' Institutes wavering between the workshop and the laboratory. ${ }^{23}$

In a key 1870 address recasting modern technical education as scientific, Dawson distinguished "mere apprenticeship" from "the greatest educational movement of our time." Advanced countries recognized science in practical, liberal arts, public, and normal schools, Dawson chided, but Canadians had ventured only so far as "to regard physical science as a necessary part of a liberal education." He dreamed of attaching a School of Practical Science and Technology to McGill's Faculty of Arts, a goal for which he confessed he would have

\footnotetext{
${ }^{21}$ Robert Lowe, "What Is Required of Our Educational Institutions," Board of Arts and Manufacture of Ontario 8, 1 (January 1868): 49-50. Joumal of the Board of Arts and Manufactures of Upper Canada: "Technical Education," 7,8 (August 1867):199-201; “A System of Education for an Industrial University," 8, 8 (August 1867): 201-2. Montréal Gazette: "Practical Education," 16 October 1868; “AAAS: A Last Review," 11 October 1869. Lewis, "Mechanics' Institutes," 232-3; J.G. MacGregor, Technical Education Abroad and at Home (Halifax, 1882) 22-23.

${ }^{22}$ May, "Report," 62-76; Association of Mechanics' Institutes of Ontario, Rules and Regulations, 1-2. Ontario Agricultural College. Review: C.A. Zavitz, "The Experimental Department of the Ontario Agricultural College, 5, 3 (1893-94): 16-17; The Course in Physics," 19, 9 (June 1907): 411-14; R. Harcourt, "Chemistry in Agriculture," 19, 9 (June 1907): 421-28.

${ }^{23}$ S to editor, 74. Joumal of the Board of Arts and Manufactures of Upper Canada: "Technical Education," 7,8 (August 1867): 199-201; ${ }^{\circ}$ A System of Education for an Industrial University," 8, 8 (August 1867): 201-2. "Experimental Department," 16-7; “Course in Physics," 411-14; "Chemistry in Agriculture," 421-28; A.B. McKillop, "The Research Ideal and the University of Toronto," in Contours of Canadian Thought, ed. A.B. McKillop (Toronto: University of Toronto Press, 1987), 85.
} 
sacrificed his geological career. A tour of American schools in 1869 persuaded Dawson to solicit private endowments locally, and he succeeded admirably within the year. ${ }^{24}$

Dawson galvanized the Montréal business community's generosity through news of plans for a rival College of Technology in Toronto. In 1871 Ontario's government named to a commission J.G. Hodgins (1821-1912), deputy superintendent of education and longtime assistant to Egerton Ryerson, whose own ill health prevented him from serving; and A.T. Machattie, former proprietor of the London Chemical Works in the riding of John Carling, Minister of Public Works and Agriculture, to whom they reported. Echoing Dawson's call for technical education as "a national necessity," the commission retraced his visits to American technical schools. Yet its recommendations reflected a Ryersonian perspective, urging that the College of Technology, or "School of Industrial Science," be left "entirely under the care, management, and control of the Government itself." These attempts to preclude university involvement in the school invited duplication of resources, and partisan revelations of confusion over the institution's purpose. ${ }^{25}$

Despite Ryerson's abjurations of a proprietary interest in the College of Technology, the project stemmed from his plans to "reconstruct" Ontario's school curriculum. He declared his longstanding intention of supplementing the "merest elements of a plain English education" established in 1846, to "supply wants as they arose." Burgeoning industries now

compelled the Department to suggest means, - - even at a later period in our educational history than it should have been done,- by which we should be able to produce skilled Artisans among ourselves.

After " 25 years of educational infancy," Ryerson warranted, it was time to complete the system's "originally planned symmetry." Intending to "stimulate interest in industrial pursuits," he introduced into schools elementary sciences related to agriculture, mechanics, and manufacturing. As an admirer of AngloAmerican schools for artisans, he explained, he welcomed a government resolution to establish the College of Technology. ${ }^{26}$

${ }^{24}$ McGill University Archives, Sir J.W. Dawson Papers, Dawson to Minister of Public Instruction, "Memo on the Subject of Schools of Applied Science," 10 December 1868; J.W. Dawson, Notes of a Visit to Scientific Schools and Museums (Montréal:, 1869); Dawson, "Science Education Abroad." Montréal Gazette:J.W. Dawson, "Technical Education in Québec," 7 March 1871; "The Facilities Now Extended by McGill," 2 June 1871; "Science Education," 8 August 1871; "McGill University, 9 September 1871; "Lecture by Professor Armstrong," 20 February 1872.

${ }^{25}$ Frost, McGill, 273-4; Dianna S. Cameron, “John George Hodgins and Ontario Education, 1844-1912," unpublished M.A. thesis, University of Guelph, 1976, 25; J. George Hodgins and Alex T. Machattie, Report of an Inquiry in Regard to Schools of Technical Science (Toronto: Queen's Printer, 1871) 5, 14-19, 24.

${ }^{26}$ Young, Early Engineering, 28-40; Hodgins, ed., Documentary History of Education in Upper Canada (Toronto: Warwick Bros. and Rutter, 1908) 22: 181-99, 204 and 23:iii, Ch. 1, and 205-19. 
J.W. Dawson was sufficiently interested in these discussions to enter the fray, reiterating his distinction between "higher and lower grades" of technical education. Canada was lacking on both levels, he held, but to varying degrees. Even applauding Ontario's recent curricular advances in science, he still saw the Ryersonian outlook as a lost opportunity to furnish the country with sorely needed technical leaders. ${ }^{27}$

The Ontario government's abandonment in September 1871 of the Normal School site, and its purchase instead of the local Mechanics' Institute building, further inflamed discussion. The Toronto Globe, among Ryerson's fiercest Liberal critics, demanded more than a glorified Mechanics' Institute. With McGill "shooting ahead" in its "sensible and praiseworthy" approach to practical science, the Globe reviled Ontario's "foolish and ill-considered technological affair" as "a palpable mistake." In May 1872 the College of Technology nevertheless opened in the typical mode of Mechanics' Institute evening classes for mechanics and other workers. ${ }^{28}$

The university was not about to abandon its interest in technical education. Dawson's Toronto colleagues shared his conviction that control over applied science teaching (as opposed to hiring professional staff for the College of Technology) had become imperative to their future. A flurry of activity behind the scenes, and the election of a more sympathetic Liberal provincial government, enabled the archaeologist (and professor of English and history) Daniel Wilson (1816-92) at University College and his influential allies-including James Loudon, now mathematical tutor at University College and lecturer in natural philosophy at the College of Technology; and Adam Crooks (1827-85), provincial treasurer, university senator, and soon Minister of Education)- to regroup their efforts. Crooks's 1873 Act to Establish a School of Practical Science (36Vic, c30) revived possibilities of moving the College of Technology to the university grounds, where it could offer day classes. In 1875 Loudon resigned from the College of Technology upon his appointment to University College, formally urging upon the government the crucial need for a university-affiliated School of Practical Science. In 1877 the College of Technology was duly renamed accordingly, with Wilson set to chair its board. In 1878 this campaign won the day as the School of Practical Science relocated to University College, which gained a laboratory building in the deal. By contrast, the establishment of Montréal's École

\footnotetext{
${ }^{27}$ Montréal Gazette: "School of Technology," 15 February 1871; "Technical Education in Toronto and Montréal," 24 February 1871; Dawson, "Technical Education in Québec," 7 March 1871. Daniel Wilson, "The Position of Science in Education," in Hodgins, ed., Documentary History of Education in Upper Canada, 25: 205-11.

${ }^{28}$ Toronto Globe: "Technology," 9 September 1871; "McGill University," 14 September 1871; "Technological Education," 15 September 1871; "Science vs. the Rule of Thumb," 2 October 1871. "Practical and Applied Science," Montréal Gazette, 19 September 1872; Young, Early Engineering, 34-40.
} 
Polytechnique in 1873 as a separate institution for engineers delayed for decades the creation of science departments in French-Canadian universities. ${ }^{29}$

\section{Roads Abandoned}

The minor key in Dawson's dream, a "system of elementary technical schools" that would prove "of incalculable importance for the working classes," lost out again. Philadelphia's Centennial Exhibition saw Hodgins "among the last to admit" Canada's "woeful deficiency" in providing "instruction in Industrial and elementary Science." With Ryerson preoccupied by his own impending retirement and his department's imminent bureaucratic overhaul, Dawson, Loudon, Wilson, and their colleagues abandoned workers to their own diminishing devices. ${ }^{30}$

Although the mostly middle-class leaders of the technical education movement insisted Mechanics' Institutes were indispensable supplements to common schools, the Montréal editors of the Canadian Mechanics'Magazine (renamed Scientific Canadian in 1880) took a less traditional tack. They argued the difficulty of drawing mechanics into evening classes lay in public education's failure to address industrialization's erosion of both the apprenticeship system and traditional avenues of employment. With Mechanics' Institutes incapable of filling this void, it fell to public schools to teach theories of heat, sound, light, electricity, and the modern languages with which comprehend them. Nor did Scientific Canadian share the universities' priorities of creating science departments. For the editors it was still the workshop, not the laboratory, that formed the nexus of a proper technical education, with scientific applications emphasized from elementary grades on up. Lamenting that workers lacked sufficient technical education to appreciate their need for it, they exhorted manufacturers to press Boards of Education for technical courses with standardized texts; integrated systems of technical universities and trade schools; and technical professionals on their councils. ${ }^{31}$

${ }^{29}$ Dawson, "Science Education Abroad"; Lewis, "Mechanics' Institutes," 225. Canadian Mechanics' Magazine: "Technical Education," 5, 11 (November 1877): 321-2; "Technical Education," 5, 7 (July 1877): 190-1.

${ }^{30}$ J.G. Hodgins, "Lessons to be Learnt by Canadians from the Centennial Exhibition," in Hodgins, ed., Documentary History of Education in Upper Canada, 28: 218-24.

${ }^{31}$ Dawson, "On Science Education Abroad"; Lewis, "Mechanics' Institutes," 225. Canadian Mechanics' Magazine: "Technical Education," 5, 11 (November 1877): 321-2; "Technical Education," 5, 7 (July 1877): 190-1.D.J. Cameron, "Montréal Technical Schools," Canadian Architect and Builder, 1, 4 (April 1888): 4-5. Globe: "Natural Science Course in Toronto University," 5 May 1883; J.S. Clark, "Industrial Drawing," in "Teachers' Convention," 12 August 1880. See also Canadian Mechanics' Magazine: 6, 3 (March 1878): 65-6; 6, 4 (April 1878): 97-8; 6, 10 (October 1878): 289-90. Scientific Canadian: 8, 1 (January 1880): 1-2;8,1 (February 1880): 33-34; 8, 8 (March 1880): 65-6; 8, 6 (June 1880): 181-2; 8, 8 (August 1880): 245-6;8,8 (August 1880): 247;8, 11 (November 1880): 341-4; (April 1881): 98-9; (May 1881): 130 . 
In 1882 the British-American technical educator Walter Smith dramatized these points in Montréal. Arguing from analogy that "Nature is really very scientific in her methods, and from the same causes produces the same results, every time," he counterposed traditional technical practices: "She never appears to resort to specifics or rule-of-thumb processes." Smith called for scientific technical education in public schools, and both

the modern university as well as the old; where the engineer, the architect, the scientist, the manufacturer, the master workman... may obtain a thorough education to fit him for the practical business he will... be engaged in. ${ }^{32}$

Neither educators nor policy-makers appeared any closer to resolving the dilemmas posed by industrial society. As Rev. James Allen (1843-1918) told Victoria University's Science Association in 1883, despite "almost universal discontent with what we have had" in education, "there is not always a clear idea of what we would have." Ontario's Minister of Education, G.W. Ross (1841-1914), determined to subsume high schools and universities in the public school system's "great stairway of learning." On yet another excursion through American technical schools in 1888, he vowed to include "work along that line" in his plan. Meanwhile, even the disparate business and labour factions of the Royal Commission on the Relations of Labour and Capital agreed in 1889 that Canada desperately needed technical schools and practical instruction in public schools. Despite prominent examples "less technical, less industrial, and more scientific and more universal," hence less threatening to trade unions, ${ }^{33}$ Ross demurred. Assuring manufacturers and labour leaders that

the corollary to the establishment by public money of a really good School of

Practical Science is that Common Schools should afford some such manual

training as would tend to discover the mechanical aptitudes of scholars, and there-

fore incline many to develop their talents by a course at the Technical School, ${ }^{34}$ he resisted any dilution of his educational meritocracy through class-based streaming of students as farmers or mechanics. ${ }^{35}$

By the late 1880 s the research ideal had gained important inroads for science in technical education, squeezing Mechanics' Institutes between a Ryersonian school orientation and the Dawsonian university-oriented approach. Now that

${ }^{32}$ Smith, Technical Education, 12-13, 51.

${ }^{33}$ "Victoria University: Presidential Address of the Scientific Association. The Choice of Subjects," Globe, 17 May 1883; [untitled], Canadian Architect and Builder, 1,7 (July 1888): 4; Greg Kealey, Introduction, Canada Investigates Industrialism (Toronto: University of Toronto Press, 1973), 15-16, 40.

${ }^{34}$ Globe: C.M. Woodward, "Manual Training," in "The Scientists," 4 September 1889; "Technical Education," 20 December 1888. "Manual Education," Scientific Canadian (March 1882): 82-3; "Manual Training," Canadian Architect and Builder 2,9 (September 1889): 100; Council of Arts and Manufactures, Québec, Committee Named to Inquire into the Question of Practical Schools, Report of a Visit to the Manual Training Scbool of St. Louis, Mo. (Montréal, 1885); C. Baillairgé, “On the Necessity of a School of Arts for the Dominion," Canadian Society of Civil Engineers, Transactions 1, 2 (1887): 68-76.

${ }^{35}$ David G. Burley, "Ross, Sir George William," Dictionary of Canadian Biography (Toronto: University of Toronto Press, 1998) 14: 888-91. 
applied science's institutionalization in higher education had acknowledged the philosopher's contribution to economic progress, would the mechanic soon catch up?

\section{SQUARING THE CIRCLE}

The 1890s brought economic change faster and more furious, with science-and universities-claiming full partnership in these prospects for economic progress. A Second Industrial Revolution saw engineers applying hydroelectricity's marvellous powers to everyday tasks; chemists refining, even synthesizing nature through pulp and paper, aniline dye, and textile industries; urban planners meeting unprecedented biochemical demands for sanitation systems; and a host of other science-based miracles. ${ }^{36}$ If intensified educational demands for science revitalized the technical education movement, they splintered it among rival visions of the country's development.

\section{New Intersections}

In its new guise as industrial research, science intertwined the interests of governments, educators, business, and labour. Business tipped the balance in this discourse, adding to the voices of traditional boards of trade and trade unions that of the Canadian Manufacturers' Association's influential trade journal Industrial Canada, founded in 1896. A proliferation of industry-specific journals joined this chorus, demanding national solutions to educational problems affecting trade and commerce. ${ }^{37}$

With science the acknowledged fulcrum of industrial progress, Dawsonian perspectives on technical education secured a comfortable upper hand. Universities portrayed their science departments and schools of practical science as indispensable to industrial growth. Britain's 1851 Exhibition Scholarships, awarded biennially from 1891 to encourage research at colonial universities in physical science and its applications, reinforced this tendency to identify science with economic progress. In this expansive environment, an enormous 1890 private endowment from the Montréal tobacco magnate Sir William Macdonald (18311917) afforded McGill three fully equipped physics, chemistry, and engineering

${ }^{36}$ Stephen Kern, The Culture of Time and Space (Cambridge: Harvard University Press, 1983); David E. Nye, Electrifying America (Cambridge, Mass.: MIT Press, 1992) and American Technological Sublime (Cambridge, Mass.: MIT Press, 1994); Charles Bazerman, The Languages of Edison's Light (Cambridge, Mass.: MIT Press, 1999).

${ }^{37}$ Canadian Engineer: Bernard McEvoy, "Technical Education," 9, 10 (1902): 267; "Instruction in Practical Science," 5, 6 (1897-98): 156-7. McEvoy, Report on Technical Education (Toronto, 1900); Canadian Electrical News 5,7 (July 1895): 113. Industrial Canada: N.E. Miller, "Technical Education," 3, 6 (January 1903): 283; "Technical Education: Memorandum Submitted to the Minister of Education, 1,8 (January 1901): 154-5; James A. Emery, "Technical Education-An Industrial Necessity," 8,3 (October 1907): 182. 
buildings, with matching professorships. Toronto too enlarged its School of Practical Science faculty and laboratory facilities, and Queen's in 1893 established a School of Mining and Agriculture. ${ }^{38}$

No longer simply aspiring to an abstract research ideal, John Galbraith (1846-1914), principal of Toronto's School of Practical Science, told an audience in 1892: "The establishment of engineering laboratories marks a new departure in technical education." Queen's principal George Grant (1835-1902) elaborated in 1894:

The man who intends to engage in any of the industrial occupations, no matter whether these are connected with manufactures, mechanism, commerce, transportation, agriculture or mining, will be handicapped nowadays unless he studies, at the very least, the specific sciences bearing on the department of industry that he has in view.

Industrialists' only alternative to becoming scientists themselves, Grant adjudged, was to employ them. ${ }^{39}$

This message was duly received. One textile industrialist affirmed in 1901:

The ideal cotton manufacturer... not only understands the arts of spinning and of weaving the cotton fibre, but is also proficient, at least to some extent, in the different branches of engineering. ${ }^{40}$

In 1905 Industrial Canada acknowledged that without the university a manufacturer's mere technical (as opposed to theoretical) knowledge proved of little use by reason of the new light which scientific research is constantly throwing upon the subject. The very foundations upon which he has built are taken from under his feet. New laws are promulgated which he is unable to reconcile with those he formerly accepted. He has not the necessary breadth of view to adapt himself to changed conditions, and if he is to continue to do efficient work he must periodically begin his weary round of studies over again. ${ }^{41}$

${ }^{38}$ Globe: "School of Practical Science," 22 March 1887; "Technical Education," 20 December 1888; "News From Montréal," 4 September 1890. Yves Gingras, Physics and the Rise of Scientific Research in Canada, trans. P Keating (Montréal, Kingston: McGill-Queen's University Press, 1991), Ch. 2; Stanley Brice Frost and Robert H. Michel, "Macdonald, Sir William Christopher," Dictionary of Canadian Biography 14: 689-94;John Galbraith, Tecbnical Education (Toronto, 1892). Canadian Engineer: "Chemical and Metallurgical Departments of McGill University," Canadian Engineer 6, 2 (February 1897): 41-3; "The School of Mines," 1,7 (November 1893): 177; "The Kingston School of Mines, "1,8 (December 1893): 209-10; "A Professor of Blacksmithing," 1, 1 (1895): 18-19. "Lectures on Electricity at McGill University," and "Constitution of the Montréal Electric Club," Canadian Electrical News 4, 2 (February 1894): 14; J.W. Dawson, "Technical Education in Relation to Mines," Journal of the General Mining Association of the Province of Québec 1 (1891-93): 91-5.

${ }^{39} \mathrm{John}$ Galbraith, Technical Education (Toronto, 1892), 6; "Principal Grant on Scientific Study," Globe, 13 October 1894.

40"Technical Education in the Cotton Trade," Canadian Joumal of Fabrics 18, 10 (October 1901): 189.

4la The University and the Manufacturer," Industrial Canada 6, 3 (March 1905): 478-9. 
In return, manufacturers stimulated university admissions by offering lucrative employment to science graduates. ${ }^{42}$

Widespread acceptance that "the industrial life of the country will be the potent influence for at least the next century" entrenched an uneasy sense of ceaseless competition. Economic insecurities found expression in post-Darwinian and militaristic outlooks, encouraging educational theories of hereditarianism and environmentalism. These led to calls for educational change as necessary adaptation in a struggle for existence, with rewards for what James Loudon, president of the University of Toronto since 1892, termed in 1901 the fittest "industrial army." Others envisioned an inexorable "industrial warfare of the future, ... which threatens to be as severe in its effects as any military campaign." "Unless we are going to go down in the struggle," agreed Industrial Canada in 1906, "we must supply a training in no way inferior to that of other countries. ${ }^{n+3}$

Competitive possibilities opened up by industrial research invited inevitable comparisons to Germany's apparent educational advantage. "No better example," exclaimed the Canadian Joumal of Fabrics in 1901, "of the interaction of universities and industrial pursuits - of pure science and technology - could be given than that of the newly effected commercial synthesis of indigo" by German chemists. "The thousands of young men who every year leave the universities, trained in scientific methods," comprised "the army with which Germany is conquering the world's markets." Industrial Canada in 1905 recognized in Germany's example that "the secret of success in trade and industry depends upon education," not only in "the library and cloister," but also in "the laboratory, the shop, and the modern lecture room."."4

\section{New Disconnections}

Although solidifying a broad public consensus that the Canadian economy needed technical education in schools as well as in universities, the new era brought less agreement than ever about what that might mean in practice. The Canadian Manufacturing Association complained in 1901:

${ }^{42}$ Ibid., 79; Thomas Shanks, "President's Address," Papers Read Before the Engineering Society of the School of Practical Science, Toronto 13 (1899-1900): 1-9.

${ }^{43} I C$ : Industrial Education," 6, 9 (April 1906): 588; "Technical Education; Memorandum Submitted to Minister of Education," 1, 8 (January 1901): 114-15; Harold Van der Linde, "Toronto Branch," 3, 1 (August 1902): 7; "Technical Education in Toronto," Industrial Canada (January 1910): 599-607. Loudon, “Convocation Address," 1, 10; James D. Allan, Report of the Council of the Board of Trade (Toronto, 1899) 12-16; "Technical Education in the Cotton Trade," 289-90; John Waddell, "Technical Education," CJF, 19, 10-11 (October-November 1902): 296, 332-3; "University and Manufacturer," 478-9; "The Manual Training Movement," Ontario Agricultural College Review 19,9 (1907): 465. Canadian Engineer. "Technical Education: A Short-Sighted Policy," 13, 9 (September 1906): 337-8; "Testing Laboratories," 15, 6 (7 February 1908): 75.

44"Technical Education in the Cotton Trade," 189-90; "Technical Education in Canada," Industrial Canada 5, 16 (January 1905): 377; Ian Dowbiggin, "Seath, John," Dictionary of Canadian Biography, 14: 918-9. 
In any municipality, there are the most conflicting views as to the subjects that should comprise a technical school course, one class of men holding that a certain range of subjects should be taught, another class opposing this view and substituting other subjects; one party insisting only upon night classes, another declaring in favor of day instruction as well, and so on with many other points of dispute. $^{45}$

There seemed "little prospect of any definite results being realized for some time," since "present plans for instruction along technical lines" remained so very "disconnected." With disconnections long endemic to the technical educational movement, science and its advocates now helped to exacerbate them. Indeed, the universities' ascendancy as purveyors of modern science manifested in their varied influences in schools.

For its part, the city of Toronto opened a technical school in 1892 to relieve pressure for workers' evening classes. The Toronto Technical School actually belied popular perceptions that labour controlled its governing board. Instead it came indirectly under the University of Toronto's curricular wing when the Toronto Technical School's university board members, led by John Galbraith, began vetting instructors' qualifications in an effort to model its programme on the School of Practical Science. Galbraith recast a familiar dichotomy to the universities' advantage, declaring the research laboratory a sine qua non of the workshop's proper functioning. Although the Toronto Technical School drew students in steadily rising numbers, appearing to herald a "much-needed reorganization" of the public school system, it remained chronically starved for equipment, partly because James Loudon's nephew, on the city's Board of Control, opposed the municipal expenditures."

As Galbraith soon realized, the Toronto Technical School did not conform easily to his institutional idea of a school. Its students' uneven educational backgrounds hampered attempts to standardize classes. Specific trades continued to be arguable teaching subjects, for while the Toronto Technical School was "supported by the public money, or the money of all trades," its labour members maligned

45 "Technical Education: Memorandum," Industrial Canada 1, 8 (January 1901): 154-5. ${ }^{46}$ Loudon, "Convocation Address," 1; "Technical Education: Memorandum," 154-5.

${ }^{77}$ Canadian Architect and Builder: "Toronto Technical School," 5, 10 (October 1892): 101-2; 7,3 (March 1894):39-40;8,11 (November 1895): 130-31. Canadian Engineer 9,2 (1902): 43; Bernard McEvoy, "Technical Education," 9, 10 (1902): 267. Industrial Canada: “Technical Education," 3, 6 (January 1893): 292; "Technical Education," 3, 6 (January 1903): 292; Van der Linde, "Toronto Branch," 3, 1 (August 1902): 6; "Industrial Education," and "The Meaning of Technical Education," 6, 9 (April 1906): 588; "Technical Education," (August 1906): 71; "Technical Education in Toronto," (January 1910): 607-8; "Some Requirements for Technical Education in Toronto," 12,5 (December 1911): 603-6. "Technical Education in Great Britain," Canadian Joumal of Fabrics 15, 11 (November 1898): 323-4; Canadian Engineer (20 October 1910): 525. The author thanks Harold Averill, University of Toronto Archives, for confirming the identity of Controller J.F. Loudon (A73-0026, 241(91)). 
such courses as potential "scab hatcheries." Nor did its one common goal, the teaching of science, help the board to agree upon appropriate instructors. ${ }^{48}$

As a Canadian prototype, the Toronto Technical School nonetheless inspired attempts to establish other technical schools across the country. To these efforts business leaders added a range of measures to train their own workers through inhouse programmes, from company shops to updated apprenticeships. From his own narrow perspective, Galbraith judged these sponsored projects "the most hopeful kind of industrial training," while even his colleagues in professional engineering rejected them as "educational campaigns for private gain. Experience has shown," warned The Canadian Engineer in 1908, "that such methods discourage and confuse the student and mislead and disappoint his employer." ${ }^{39}$

\footnotetext{
${ }^{48}$ Galbraith, Tecbnical Education, 6-7; “The Remedy for Inefficient Labor," Industrial Canada 8, 8 (1908): 630.

${ }^{49}$ A.H. Holdich, "On the Establishment of Science Classes, etc.,"Joumal of the Canadian
} Mining Institute 2 (1899): $21-4$. Industrial Canada: "Montréal Technical Institute," (May 1903): 447-9; "Will Give Technical Training," 8, 5 (December 1907): 412; F.H. Sexton, "Technical Education in Nova Scotia," 9, 3 (October 1908): 192; “An Experiment in Technical Education," Industrial Canada 9,9 (April 1909): 738-9. "University of Manitoba Engineering Department," Canadian Engineer (7February 1908): 76; "The Hamilton Technical School," Canadian Machinery 4 (1908): 29-30; Canadian Mining Joumal (15 January 1909): 48-51; L.C. Harkness, "Technical Classes in Manitoba Agricultural College," Canadian Machinery (1910): 41-3; "Address by F.H. Sexton, Director of Technical Education, Nova Scotia," Canadian Mining Joumal (15 July 1910): 435-6; L.G. Dennison, "The Montréal Technical School, Its Mission and Equipment," Canadian Machinery (1911): 261-4; "New Technical School in Montréal," Industrial Canada 12, 1 (August 1911): 55-6; "New Technical School in Winnipeg, Manitoba," Canadian Engineer 23 (1912): 402; Thames, "Industrial Education in London, Ont.," Canadian Machinery (1912): 38; F.H. Sexton, "Technical Education in Nova Scotia," Industrial Canada (November 1913): 445-8; "Industrial Education in Ontario," Industrial Canada 13, 9 (April 1913): 1219-24. W.P.R., "Students' Course at the Canadian General Electric Company's Shops," Canadian Engineer 3, 12 (December 1895): 325-6; "Technical Education in the Woollen Industry," Canadian Joumal of Fabrics 19, 1 (January 1902): 1-2; N.E.Miller, "Technical Education," Industrial Canada 3, 6 (January 1903): 282-3; "Technical Education in the PaperTrade, "Pulp and Paper Magazine 1, 4 (August 1903): 100-1. "Report of the Technical Education Committee, Industrial Canada 7, 3 (October 1906): 216-8; "Education of Workmen in Trade Schools," Industrial Canada (January 1907): 511-12; "Progress of Technical Education Abroad," Industrial Canada 10, 6 (January 1910): 586-7; Robert Patterson, "Technical and Industrial Education for the Mechanic," Canadian Machinery (1912): 6-8. “Apprenticeship Articles," Industrial Canada 4, 8 (March 1904): 410-1; J.P. Murray, "Apprenticeship and Technical Education," Industrial Canada 7, 2 (September 1906): 106-8; "Training Boys to be Efficient Workmen," Industrial Canada 7, 5 (December 1907): 433-5; “Practical Work in Training Workmen," Canadian Machinery 7, 12 (1907): 917; "Training Mechanics," Canadian Engineer (17 December 1907): 660; "The Apprentice, How the Apprentice Got Even with the 'Smart" Mechanic," Canadian Machinery 4 (1908): 61-2; "C.P.R. Apprentice Scholarships," CM (1907): 8; "Onlooker," "Tommy Fairfield's Experience with an Automatic Machine," Canadian Machinery and Manufacturing News (1909): 42-3; "Co-Operative Technical Education," Canadian Machinery and Manufacturing News 6, 5 (May 1910): 42-3; Jas. P. Murray," "Technical Education and Apprentices," Industrial Canada, 11, 4 (November 1910): 455; "A Phase of Technical Education," Canadian Machinery and Manufacturing News 8, 10 (October 1912): 309; Albert H. Leake, "Industrial Education: Its 
Nor did Galbraith resist the Canadian Manufacturing Association's attainment of permanent positions on the Toronto Technical School board in 1902. This achievement emboldened manufacturers to expect inclusion "on any new Board formed to look after the Educational interests of the city." It formed part of a larger campaign launched by boards of trade in 1901 (with the Canadian Manufacturing Association appointing standing committees in 1904) to lobby for a national system of technical education that would supply efficient, docile workers on demand. Boldly rejecting government stonewalling over potential constitutional conflicts, these outspoken pressure groups cited as precedents science and engineering taught in military schools, as well as agricultural and biological research stations, all federally funded. ${ }^{30}$

High schools felt these larger forces, especially when Ontario universities added science to matriculation requirements by the late 1890 s. University faculty mentored teachers who set about creating science departments with laboratory facilities of their own. Yet these new relationships left them little room for curricular manoeuvre, devaluing subjects of lesser interest to universities. G.W. Ross's Technical Education Act of 1897, supporting manual and agricultural training in Ontario schools on voluntary principles, squeezed trustees and teachers between public demands for more practical offerings, and stricter matricular prerequisites. Ross then ducked public scrutiny by citing teachers' passive resistance when surprisingly few schools took up the opportunity to teach technical subjects. ${ }^{31}$

Among those urging high-school teachers to fight any breach of traditional curricular content was James Loudon. Addressing convocation at the University of Toronto in 1899, he deplored the proposed extension of manual training and household science into high schools, as inaugurated in Halifax in 1891. Invoking the College of Technology's false beginnings, he insisted

Methods, Problems and Dangers," Industrial Canada 13,6 (January 1913): 860-1. Galbraith, "Technical Education," 525; "Industrial Education," Canadian Engineer 15, 19 (8 May 1908): 332; Luc Chartrand, Raymond Duchesne, and Yves Gingras, Histoire des sciences au Québec (Montréal: Boréal, 1987), 239-40.

${ }^{50}$ IC: “Toronto Branch," 3, 7 (February 1903): 317; "Technical Education," 1, 10 (March 1901): 209; "Technical Education in Montréal," 2, 11 (July 1902): 427-8; "Technical Education in Canada," 5, 6 (January 1905): 376; "National Technical Schools, "6, 6 (January 1906): 368-9; "What Technical Education Should Be," 6, 12 (July 1906): 850; "Technical Education," 7, 1 (August 1906): 71; James A. Emery, "Technical Education-An Industrial Necessity," 8, 3 (October 1907): 181; “Do Our Schools Produce Artisans?" 9, 2 (July 1907): 916; "The Remedy for Inefficient Labor," 10,8 (March 1908): 628-30. "Technical Training in Canadian Textiles," Canadian Joumal of Fabrics 18, 4 (April 1901): 97-8; "Technical Education and the Federal Government," Canadian Mining Joumal (1907):590-1; Murray, "Technical Education and Apprentices," 455.

${ }^{31}$ Globe: "Teachers of Science," 4 January 1890; “Science Teachers' Association," 30 December 1890; "The Teachers in Session," 5 April 1893; "Education Association," 7 April 1893. John Millar, Technical Education (Toronto, 1899), 9-11; "Technical Education," Canadian Joumal of Fabrics 16, 6 (June 1899): 163-4; Lieut.-Col. Farewell, Papers on Technical Education (n.p., 1899), 6-7; McEvoy, Report on Technical Education; "Technical Education," Canadian Joumal of Fabrics 16, 6 (June 1899): 162-3. 
The High School is, or should be, concerned in general, not technical, training.

It has already been complicated and diverted from its object by the introduction of technical and semi-technical subjects, and to proceed further along the same line would be to further impair its usefulness. ${ }^{52}$

Loudon demarcated "the true line of progress" not in muddied high school purposes, but in "the cooperation of capital and enterprise with high technical knowledge." His Darwinian mantra remained:

No diffusion of technical training will in itself be effective if we do not take care to maintain the higher and the highest kind of scientific instruction, and if our manufacturers do not utilize this expert knowledge. ${ }^{53}$

At bottom the desire for technical education necessitated hard choices. After conducting yet another tour of American technical schools for the Ontario government in 1899, the Toronto writer Bernard McEvoy (1842-1932) paid only lip service to workers' education. German competition had moved him instead to recommend "turn [ing] out fully equipped captains of labor-engineers, architects, chemists, managers, foremen, etc."

Only the students who proceed to the higher and more complete courses of instruction are likely to have any influence on the development of our trade, [making it] more important from the point of view of industrial development to spend money for the assistance of students who will devote themselves to a course extending over several years than to lavish it in scattering broadcast a knowledge of elementary science. ${ }^{54}$

This Dawsonian preference for higher technical education never led to a feeder system. In the stark light of industrialism, the schools' liberal arts curriculum struck some educators and businessmen as a useless evolutionary vestige, choking off the adaptive growth of a modern technical education. In 1905 Industrial Canada quoted Ross's successor Richard Harcourt (1849-1932) as attributing to "the extreme conservatism of the large majority of people," including teachers and trustees, the survival of such educational remnants "in the prominent place they have occupied in the curricula of European countries all through the dark ages down to the present time." Yet although Germany, France, and other countries had "long since passed" the "experimental stage in technical education," the classics still "inspired the guardians of our public schools with a certain amount of religious awe." Canadian efforts to update the curriculum met with "stubborn opposition." Canadian Manufacturing Association members found refreshing the stunning response by one "progressive" 'Toronto school

${ }^{52}$ James Loudon, Convocation Address (Toronto, 1899) 7, 9, 12-14.

${ }^{31}$ Loudon, Convocation Address, 12-14; "Scientists in Session, " Globe, 17-18 August 1897; James W. Robertson, The Macdonald Sloyd School Fund (Ottawa, 1899); Frost and Michel, "Macdonald," 692; John Seath, Manual Training and High School Courses of Study (Toronto, 1901); Lois K. Yorke, “McKay, Alexander," Dictionary of Canadian Biography, 14: 708.

${ }^{54}$ McEvoy, Report on Technical Education, 9-10 and "Technical Education," 266-8. 
principal: that he "should like to see about two-thirds of the high schools of this Province closed up or else turned into technical schools. ${ }^{\text {"55 }}$

An important move finally to close the gap between liberal and technical streams came from the universities. The manual training movement that had taken hold abroad decades earlier, now found nurture in Canada through collaboration between the Montréal capitalist Sir William Macdonald and the Dominion commissioner of agriculture and dairying J.W. Robertson (1857-1930). Robertson, a Scottish-born former professor at the Ontario Agricultural College, persuaded Macdonald in 1899 to proffer seed money nation-wide for manual training in public schools.

Robertson struck a resonant chord by couching his arguments in the language of Scottish philosophical idealism, which had gradually supplanted the older Scottish Common Sense to become "the major force in the intellectual life" of English Canadians in the generation before 1914. This neo-Hegelian world view was rooted in post-Darwinian evolutionary and other naturalistic approaches of modern science. It offered refuge from the ruthless Spencerian ethic that troubled many of the Christian faithful - especially university students, who found themselves on the front lines of exposure. Like their French-Canadian counterparts several decades earlier, these philosophical idealists rejected as illusory the traditional dualism of mind and body. Instead they valued individual "self-realization" through a fuller appreciation of "actual experience" in all its dimensions. Their concomitant "sense of mission and stewardship" advocated an orderly transition to industrial society through myriad forms of "applied idealism," spreading from the academic to the public sphere via the "new education" in public schools, ${ }^{56}$ with important implications for technical education.

A quintessential applied idealist, Robertson drew upon his lifelong evangelical "ideal of service," exhorting Canadians to anticipate "the joy of clear apprehension" that would fulfill new generations of students under his proposed programme:

\footnotetext{
${ }^{55}$ Dowbiggin, "Seath," 918; "Ontario Educationists," Globe, 6 April 1893; James D. Allan, Report of the Council of the Board of Trade (Toronto, 1899): 3; Farewell, Paper on Technical Education, 7-8; W.S. Ellis, A Report on Elementary Technical Education for Ontario (Kingston, 1900) 5-8; "Technical Education in the Cotton Trade," 289-90; "Toronto Branch," 7; "University and Manufacturer," 478. Industrial Canada: "Technical Education in Canada," 5, 6 (Jan. 1905): 375-6; R.A. Falconer, The Relation of the University to the Industrial Life of the Nation," (May 1911): 1060; F.W.Taylor, "What is Scientific Management?" (April 1913): 1224-25.

${ }^{56}$ J. Clark Murray, The Dualistic Conception of Nature (Montréal, 1896); Arthur O. Lovejoy, The Revolt Against Dualism (New York: W.W. Norton, 1930); A.B. McKillop, Matters of Mind (Toronto: University of Toronto Press, 1994), 187-92, 202, 213; Wood, Idealism Transformed, 21-5; Gidney and Millar, Inventing Secondary Education, 316; Suzanne Zeller, "Environment, Culture, and the Reception of Darwin in Canada, 1859-1909," in Disseminating Darwinism, ed. Ronald L. Numbers and John Stenhouse (Cambridge: CUP, 1999), 108-9.
} 
When scholarship and practical and manual instruction join hands in the schools to train the whole child, children will leave school facing aright, capable and happy in making the right things come to pass, at the right time and in the right way. ${ }^{57}$ The object of education, the real controlling influence which shapes its direction, depends on the ideals of the people. When the mothers want to see their sons ministers, and doctors, and lawyers and such, unconsciously perhaps but certainly, the schools will be turned that way.... [But] If the supreme desire be that the children, and the grown people, shall be happy and capable, in the sphere of life in which they are to live, then the education and educational processes should be directed to attain these ends. ${ }^{58}$

Robertson justified manual training in monist terms, typically envisioning a pupil as "one and indivisible, a being with physical, mental, and moral qualities and powers." "Surely [therefore] a school course [was] deficient which does not provide as fully as is practicable for the development and training of faculties of the body, mind, and soul." Far beyond merely "adding a new subject of study to the already over-burdened school course," he preferred an integrated "educational process to train the useful faculties of the mind and body." Industrial Canada quoted Dr. J.A. McLellan, principal of the Ontario Normal College, in 1905:

Heretofore there has been a mischievous divorce between brain and hand, arising, no doubt, from an unphilosophical dualism, not to say antagonism, between nature and man, things which cannot be put asunder in sound thinking. ${ }^{59}$

Robertson's idealist rhetoric masked the paternalistic élitism of many concerned colleagues. In 1894 the engineer Charles Baillairgé (1826-1906) warned "too much education" left the agricultural and working classes unfit for their stations in life, and frustrated as "second and third class professionals of every hue, with little or nothing to do; with mischief and discontent and anarchical tendencies following in their wake." A Toronto convention of boards of trade in 1899 heard G.W. Ross agree that "the young people of the country were disposed to prepare rather for the professions than for industrial pursuits" (which Ross ascribed to "social conditions" more than to his own policies). Although recognizing "There was not room for the higher education for everybody in Canada," the convention could not decide whether technical and public education should follow parallel or integrated paths. ${ }^{60}$

Robertson espoused the latter choice, echoing widespread conservative desire for social harmony, "a link of sympathy for labor and all engaged in it in all classes of society." He attributed society's "preference for clerical, professional

${ }^{57}$ University of British Columbia Archives, J.W. Robertson Papers, Box 1, Folder 1, Ishbel Robertson Currier, “Brief Biography of J.W. Robertson” (typescript), 1-3,33-4; Robertson, Macdonald Sloyd, 6, 23, 26-7; J.W. Robertson, Improvement of Education in Rural Schools (Ottawa, 1901).

${ }^{58}$ Robertson, Macdonald Sloyd , 20.

${ }^{59} \mathrm{Ibid}$, 22-3. Industrial Canada, : "Technical Education in Canada," 5, 6 (January 1905): 375; "The Remedy for Inefficient Labor," 8, 8 (March 1908): 628.

${ }^{60}$ Charles Baillairgé, Technical Education of the People in Untechnical Language (n.p., 1894), 41-2; "Technical Education," Canadian Journal of Fabrics, 16, 6 (June 1899): 162-4. 
and scholastic occupations, [even] in those who have no natural fitness for them, and the corresponding distaste for manual and bodily labour", not to "overeducation" but "over-schooling." The "too exclusively book and language studies of the common schools" burdened students with "mental dyspepsia" and led many to flee rural for urban employment. Robertson prescribed manual and practical instruction as "an educational means for developing intellectual and moral qualities of high value, in all children, without particular regard to the occupations they are to follow afterwards." Skirting labour's objections to "turning out workmen from the Public schools," he hoped to edge manual training into the curricular mainstream as "educational hand-work, not trade hand-work," indeed "not technical education" at all, but preparation for it. ${ }^{61}$

Robertson cast some well-baited hooks, but few fish were biting. His integrative view of manual training in education was rejected not only from the scientific perspective of the University of Toronto's President Loudon, but also from the humanistic view of Queen's University's professor of English, James Cappon (1854-1939). A Scottish philosophical idealist trained at Glasgow, Cappon believed that technical education had its proper place, and ought never usurp the absolute primacy of literary culture in a modern education. ${ }^{62}$ In 1905 he published a critique in the Queen's Quarterly accusing Robertson of falsely dichotomizing words and things, abstract and concrete approaches to learning:

Notwithstanding all his great practical gifts and his specific excellence as an organizer of practical education, Prof. Robertson's general theory of education does not seem to me to be quite safe or sound as a whole... I am sorry to see him identifying a cause which is so good with theories which are so doubtful..$^{63}$ Chafing, Robertson replied that he did favour literary training, if only in "as large an amount as the capacity of the student and his opportunity make feasible," and as long as practical courses were not kept "subordinate" to it. ${ }^{64}$

Robertson's wounded defensiveness rang hollow to anyone who shared Cappon's righteous alarm, and his approach found no place in the most advanced Canadian technical educational reforms of the day. In Ontario, Richard Harcourt evinced few of his predecessor's qualms about streaming students. In 1904 he ęnumerated seven different high school programmes: general, commercial, manual training, agriculture, domestic science, normal school entrance, and university matriculation. Pressure to integrate technical education more generally in Ontario schools intensified when Harcourt appointed the high school inspector John Seath (1844-1919) superintendent in 1906. In Nova Scotia, similar forces saw the Halifax school board cooperate with the new Department of Technical Education, under F.H. Sexton's direction, to establish the Halifax Evening Tech-

61"Technical Education," Canadian Journal of Fabrics, 163; Robertson, Macdonald Sloyd, 5-7, 22-3; cf. "Technical Education in Canada," Industrial Canada, 5, 6 (January 1905): 375.

${ }^{62}$ S.E.D. Shortt, The Search for an Ideal (Toronto: University of Toronto Press, 1976), 71.

${ }^{63} J a m e s$ Cappon, "Sir William Macdonald and Agricultural Education," Queen's Quarterly, 12, 3 (January 1905): 315, 322.

64.W. Robertson, "Professor Cappon's Article," Queen's Quarterly, 12, 4 (April 1905): 424. 
nical School in 1907. None of these developments--including Seath's Industrial Education Act of 1911 and the subsequent appointment of F.W. Merchant as Ontario's Director of Technical and Industrial Education-resulted in the fuller assimilation Robertson would have wished. A prizewinning 1913 essay by A.H. Leake conceded that, despite these careful efforts to synthesize rival viewpoints, "Manual training has never been taken seriously by the public." ${ }^{\text {"65 }}$

If the increasingly diversified "movement" for technical education was ever to reap results, it required leadership. In 1899 the Toronto Board of Trade anticipated "great honour awaiting the man who devised a practical method... to bring practice and theory into unity, and then thoroughly equip the youth of the country for the battle of life." But where was the Canadian businessman to fund scholarships in this field? Where was the

one man or body of men invested with sufficient authority to thoroughly examine the different and sometimes conflicting views advanced, to weigh them and give them their proper importance, and to map out a definite line of action? Where was the

Canadian Colbert-some far-seeing statesman-who will inaugurate a complex system of Dominion aid to scientific and technical education?"

Leadership of a political sort arrived ostensibly with the Liberal Minister of Labour, W.L. Mackenzie King (1874-1950), at whose behest the Royal Commission on Industrial Training and Technical Education undertook its national inquiry in 1910. In structure and outcome the commission gave early expression to King's developing ideals of industrial efficiency, industrial democracy, and industrial peace. It combined a naiveté toward corporate capitalism with a paternalism toward the working classes that found fuller formulation in King's own Industry and Humanity (1918). ${ }^{67}$

But had King chosen his chief commissioner, J.W. Robertson, wisely? Robertson seems, at least in hindsight, to have hit his technical educational stride by 1905 , and not made much headway since. The Royal Commission on Industrial Training and Technical Education may have been well-placed in principle to lay concrete plans for technical education in Canada, but its report mainly reiterated Robertson's original message, substituting federal funding for his earlier bene-

${ }^{65}$ Leake, "Industrial Education," 860; Dowbiggin, “Seath," 918-9; Yorke, “McKay," 707-9; Macleod, "Practicality Ascendant," 53-92; Guildford, "Coping With De-Industrialization," 69-84.

66“Technical Education," Canadian Joumal of Fabrics, 16, 6 (June 1899): 163; "Technical Education in the Cotton Trade," 289-90; "Technical Education: Memorandum," 154; W.L. Goodwin, "Technical Education and the Federal Government," Canadian Mining Journal, (1907): 590-1.

${ }^{67}$ Canada, House of Commons, Sessional Papers, 191d, P.C. 1133, Royal Commission on Industrial Training and Technical Education [Royal Commission on Industrial Training and Technical Education], Report, Part I (Ottawa, 1913) vii; "Technical Education Commission," Canadian Engineer, 19, 5 (4 August 1910):126-7; D.J. Bercuson, Introduction to William Lyon Mackenzie King, Industry and Humanity, reprint ed. (1918; Toronto: University of Toronto Press, 1973), viii-xxiv. 
factor. The commission's mandate-to realize a younger generation's Progressive ideals through King's assumption that "industrial efficiency" could "best be promoted by the adoption in Canada of the most advanced systems and methods of industrial training and technical education, ${ }^{n 68}$ - hardly suggests Robertson as King's man. The commission's firsthand inspection of the German system encountered what Robertson judged to be unCanadian basic values. German technical education "appeared to us to be regarded as a great national service whereby all the individuals are being trained... in the interests of the State." In contrast, Robertson ranked

the first and chief object of industrial training and technical education in Canada the personal welfare of the individuals who are to participate in it; second, the prosperity and strength of the State; and, third, the advancement and improvement of industry as such, and that only as consistent with and subordinate to the other two. ${ }^{69}$

To his surprise, German educators evinced not "brag or self-satisfaction" at their own accomplishments, but the same insecurities plaguing their competitors abroad. ${ }^{70}$

Robertson cast his Report in the same idealist language that failed to sell his plans earlier. It was even less likely to do so during the hothouse flowering of industrial research induced by the Great War. He continued to interpret modern civilization's "obstrusively commercial and industrial" mode in an essentialist way: "The forms themselves are ever changing, while the inner force which uses them persists." He believed "the inner power of the people expresses itself progressively in human qualities and social and economic conditions," and credited the country's rapid recent development to the "application of science and scientific methods to all forms of production, construction, conservation and administration." Robertson reiterated his charge that while "changed social and industrial conditions" compelled schools to evolve, the latter had not maintained "points of contact with or relation to industrial, agricultural, or housekeeping life." "The deep of the ages in human life was calling to [students'] complex instincts and aptitudes," he still lamented, "but the schools turned a dull ear." Instead of "the scientific spirit" that should result, public education imbued them with "distaste for manual labour." ${ }^{\text {11 }}$

Despite Industrial Canada's confidence that such difficulties would vanish over time, "as the theory and practice of industrial education are better understood," Robertson woefully misread his most crucial constituents. Despite his best efforts

${ }^{68}$ W. Stewart Wallace, ed., Macmillan Dictionary of Canadian Biography, 4th ed., rev. W.A. McKay (Toronto: Macmillan, 1978) 710; Frost \& Michel, “Macdonald," 692-3; Edwin John Pavey, James Wilson Robertson: Public Servant and Educator, unpublished MEd thesis, University of British Columbia, 1971; Royal Commission on Industrial Training and Technical Education, Report, vii.

${ }^{69}$ Royal Commission on Industrial Training and Technical Education Report, 5.

${ }^{70}$ Ibid., 19.

"Ibid., 11-19. 
over the previous decades, almost 70 years after Ryerson and Dawson had formulated their separate outlooks "educators who have made a study of it" still divided over the extent to which technical education should be incorporated into public school systems. ${ }^{2}$ And no wonder, with Robertson still precociously attesting

The work of the school day should gradually be arranged less and less on subjects as such and more and more on occupations, projects and interests, each of which would form a centre for the correlated study of several subjects such as reading, composition, number work, writing and drawing. ${ }^{73}$

Ontario's Industrial Education Act was intended to control the flow of labour by offering opportunities to establish industrial, technical, and art schools based on local need. Manufacturers questioned the wisdom of this, arguing it fostered "a growing disposition to lose sight of the education feature and to glorify the institution." In 1913 the Canadian Macbinery and Manufacturing News observed

We talk about the mad rush among the nations of the world to increase armaments, but who shall deny that there is more of necessity and wisdom in the latter than belongs to technical school buildings and equipment [if the desired education did not result]? ?"4

Failing to rally educators, politicians, or manufacturers, Robertson only alienated parents. His idealist concern for "the preservation and strengthening of a spirit of willingness to accept and fill one's place in organized society which implies relative positions and relative degrees of authority ${ }^{\text {n75 }}$ overlooked the reality of increasing social mobility-and with it rising private, if not yet public, expectations-entailed by Canada's economic expansion. As A. H. Leake understood in 1913:

The average parent desires 'education' for his boy, in order that he 'rise above' the occupation of his father and the ordinary walks of life. Theoretically they believe thoroughly in the advantages of industrial education, but if it is to lead to work at the bench it is for the other man's son and not his own. ${ }^{76}$ "Most of our propaganda, like the work of the ministers," concluded Leake, "has been preaching to the converted, and has not reached those for whom it was designed." 77

The The Canadian Engineer and The Canadian MiningJournal questioned the Royal Commission on Industrial Training and Technical Education's exclusion

${ }^{72} I C$ : “Industrial Education in Ontario," (April 1913): 1220; “Suggestions for Technical Education," 11, 4 (November 1910): 453-4.

${ }^{73}$ Royal Commission on Industrial Training and Technical Education Report, 10.

${ }^{74}$ Dowbiggin, "Seath," 919; John Seath, Education for Industrial Purposes (Toronto, 1910); "Industrial Education in Ontario," Industrial Canada (April 1912): 1219; "The Purpose of Technical Schools," Canadian Macbinery and Manufacturing News 9, 13 (17 April 1913): 414.

${ }^{75}$ Royal Commission on Industrial Training and Technical Education Report, 19.

${ }^{76}$ Leake, "Industrial Education," 861; “Industrial Education in Ontario, Industrial Canada (April 1913): 1219.

"Leake, "Industrial Education," 861. 
of applied science faculty. ${ }^{78}$ Yet in a highly publicized lecture on "The Relation of the University to the Industrial Life of the Nation" in 1911, James Loudon's successor as president of the University of Toronto, R.A. Falconer, seemed unconcerned. He instead marvelled at modern science's relatively recent historical rise to prominence:

Ideas, methods, and discoveries, many of them by no means new or recent, suddenly burst into flower and fruit under the ripening atmosphere of the age.

Physical science grew apace. Applications of scientific results to industry created new industries or revolutionized old ones. ${ }^{79}$

Like his Dawsonian predecessors, Falconer gloried in the university as a place where "the profound unity of our industrial life becomes manifest." He lauded science's empowerment of "the energy and will of the capitalist" to "set into motion the machinery of our modern world." $\mathrm{He}$ also inherited his predecessors' fear, in workers' technical education, of a curtailment of resources to train industrial leaders. In a remarkable display of self-involvement, Falconer deemed the universities' creation of a need for workers' education sufficient assurance that it would eventually come about. ${ }^{80}$

Science succeeded so well in making change the expected order of the day that it hardly mattered what the Royal Commission on Industrial Training and Technical Education decided. Its suggestions, "although applicable at the time of the preparing of the report," opined The Canadian Engineer, "may in one year have so little direct bearing upon the then present educational matters as to appear absurd." At the very least, it seemed imperative that the commission "clear the air by authoritatively defining" technical education. This meant a recognition not only of science, but of its fruitful partnership with capital: "Professors in the engineering colleges," Industrial Canada assumed, "must be men with a commercial instinct." ${ }^{81}$

Science's practical powers had been confirmed through industrial research. Boosters, especially in the universities, had no need to champion technical education as anything other than applied science. Much of technical education had already been thoroughly scientized. Its elementary forms, including industrial and vocational education, promised far less hope of advancement in an increasingly scientific world. Robertson's Report, filed on the windward side of 1914 where the cultural environment still cherished the liberal arts, offered a curiously anachronistic - and thereby largely ineffectual-amalgam of past and future, with a static

78a"The Technical Education Commission," Canadian Engineer (10 June 1910): 576; "The Royal Commission of Inquiry on Technical Education, " Canadian MiningJournal 31, 14 (15 July 1910): 417.

${ }^{79}$ Falconer, "Relation of the University," 1059.

${ }^{80}$ Ibid., 1060-1.

${ }^{81}$ “Technical Education, Utility Schools, Artisan Schools," Canadian Engineer, 19, 16 (20 October 1910): 15; "Technical Education," Canadian Machinery 10 (1913):10; "Suggestions for Technical Education," Industrial Canada, 11, 4 (November 1910): 453. 
view of a hierarchically ordered society on the one hand, and harsh dismissal of a general education on the other.

The power of liberal education later in the 20th century was quite another matter. The Canadian economy continued to be dominated by staple production, and Thomas Hobbes's trenchant 1661 observation that "Ingenuity [ingenium] is one thing, and method [ars] is another, ${ }^{, 82}$ still rang true for Victorian educators. They were struggling not merely with each other but against deeply held assumptions about the proper measure and the proper venue for technical education. Powerful precedents weighted the case of Ryerson vs. Dawson well before it began, and these "school promoters" in turn influenced what followed. The plot used borrowed props and devices, but unfolded distinctively on the Canadian stage.

The author thanks various anonymous readers for helpful comments. She gratefully acknowledges financial support for this research from a grant funded partly by Wilfred Laurier University Operating funds, and partly by the SSHRCC General Research Grant awarded to Wilfrid Laurier University.

${ }^{82}$ Shapin and Schaffer, Leviathan and the Air-Pump, 347. 